\title{
Culture versus Higher Education in the Development of Africa Today
}

\author{
YahayaAliyuSaidu \\ Department of Education, Umaru Musa Yar'adua University,Katsina, Nigeria \\ Being a Paper for International Conference, 19-22 June, 2012, Faculty of Education Kampala International \\ College, Dar essalam, Tanzania.
}

\begin{abstract}
The importance of emphasis on cultural values in the development and management of higher education in Africa to all educational administrators and planners of all types and levels of African Higher education cannot be over emphasis. This paper provides an eagle's eye view of the topography of culture in Higher education in particular from an insider's perspective in the $21^{s t}$ century. This paper does not claim to be conclusive but presents important issues for careful reflection, to provoke discussion on the relationship between culture and education. The paper is not empirical but it is located on sound knowledge and careful observation within African context of culture and Higher education in a global world as viewed by the writer. The paper raises issues around curriculum and management of Higher education in Africa. Thus it has examined the concept of culture, Higher education and their relationship particularly in this age of globalization in Africa. It equally analysed the cultural role ambivalence of education in African countries and made some recommendation on how to utilise this variable to make African Higher educational system achieve its educational aims and objectives and make African Countries great in the nearest future. Methodically, the paper is a product of careful observation and reflections on direct participation in Higher education production and conclusion from studies in the fields of higher education and human values in Africa.
\end{abstract}

\section{Introduction}

Culture and education are words that are often placed side by side in any order of preference. The sequence of the words belies the truth that these are interchangeable and mutually reinforcing expressions of meaning. There is therefore the recognition that "education" and "culture" are interlinked and it is truly not possible to have one without the other. One presumes that this topic is of pertinent interest to the African Union and its programmes for the advancement of the Objectives set out in the Constitutive Act of the African Union, 2000. In particular that the AU should achieve greater unity and solidarity among African nations and peoples, accelerate socio-economic and political integration, promote sustainable development and advance research especially in science and technology (Article 3). The purpose of this paper is to explore the linkages between culture and education and examine the processes of knowledge formation and developments from an African perspective.

Higher educational institutions and education are considered as the cradle of future decision-makers, reservoirs and change agents for the society. To re-engineer this type of education for optimal relevance and performance, critical balances need to be maintained, which includes: technological modernity versus cultural preservation; growth versus equity; internationalism versus local or national relevance; and individual development versus cohesion. Thus Higher Educational Development and Planning involves more than a mere programme expansion or mere calculation of number of such institutions. It is not just a business of scientific forecast and estimation. There are political and socio-cultural dimensions to it. Technocrats as well as politicians have their vital role in it. In other words Higher Educational expansion and development in a social and political environment like African countries involves more than technical rationality. Just as Gross as cited by Wirt, E M \&Krist, M W (1972) defined it as

"an exercise in conflict management rather than only the sober application of technical rationality. Any real life planning process may be characterised as a stream of successive compromises punctuated by frequent or occasions of deadlock - victories, defeats and integration"

As such, it can be emphasised that social as well as political environment which is the rudiment of culture is perhaps one of the fundamental challenges faced by Higher Education in Africa. However, the most serious question is whether native culture should be the core driver or that the global agendas should drive higher educational policy, innovation and institutional practice. The congruent argument is that higher education needs to lead a reform agenda as dictated by a broad social mandate premised on providing relevant and innovative Higher Education. Thus Higher Institutions need to be communities of practice, leading change and innovation. 
The issues raised in this paper are reflections on the challenges posed by culture on higher education in this era of globalization. An attempt has been made on how to deal with such challenges. The reflections are guided by two questions: Should native culture be the driver of higher education planning and reforms in Africa? Or should global trends be the driver of higher education in Africa?

\section{Concept of Culture}

Mendoza and Napoli (1973) have indicated that Culture is a learned and shared way of life that is socially transmitted from one generation to the next" For an effective and efficient living, a community, society or nation must certify certain universal needs. These universal needs includes the need for language, the need for status ranking for role distributions and functions, the need for family life as a basic unit of social organisation, the need for systematic method of procuring basic necessities of life like food, shelter and closing, the need for government and law, the need for religion and ethics, the need for ways of explaining natural phenomena (magical, Scientific ways) and the need for expressing one's sense of beauty.

The contents of culture consist of customs, beliefs and artefacts and value system.

- Customs refers to how members actually behave. This includes eating habits for example the use of hand, fork, knife \& spoons, chop-sticks as in China.

- While the beliefs system covers system of ideas that dictate standard of what is right or wrong and meaning of life on the basis of Religious, Magical, and Normative prescriptions of conduct. In some African culture these may complement each other but in countries like USA, it neither defined nor consistent.

- Artefacts are objects produced and shaped as fundamental needs and requirement of daily life by the members of the community, society or a nation. It may be designed or borrowed from others and incorporated. Such includes hoes, cutlass, pots, chairs, tables, and cooking stove among others.

It is noticeable that the view of culture in many international institutions, especially those of UNESCO regard it as formalist and denuded of its radical character. For example the UNESCO Declaration on Cultural Diversity (2001) refers to culture as the "distinctive spiritual, material, intellectual and emotional features of society or social group, and that it encompasses, in addition to art and literature, lifestyles, ways of living together, value systems, tradition and beliefs." The value of the Declaration, lies in the extent to which it makes the connections between culture and education explicit: that it is "at the heart of contemporary debates about identity, social cohesion, and the development of a knowledge-based economy".

There is also the developmental approach to culture that the declaration espouses: "Cultural diversity widens the range of options open to everyone; it is one of the roots of development, understood not simply in terms of economic growth, but also as a means to achieve a more satisfactory intellectual, emotional, moral and spiritual existence" (Article 3). UNESCO has gone further. In its latest Convention on the Protection and Promotion of the Diversity of Cultural Expressions adopted by the General Assembly of UNESCO at the $33^{\text {rd }}$ Session in Paris in October 2005, UNESCO emphasises the interrelationship between education and culture as preconditions for sustainable development.

Culture can be classified according to the degree of its complexity. Such classification covers, Cultural Traits, cultural complexes and cultural patterns.

- Culture Traits: this refers to the smallest unit of a cultural entity that has significance for the rest of culture. This can be material or non material aspect of culture and may represent a combination of materials, acts and ideas. For example presentation of kolanutsat a ceremonies in southern Nigeria requires artefacts such as kolanuts, bowl, and norms of breaking the kolanuts, who and how it should be shared. Other examples may include modes of greeting elders in Yoruba land, Hausa land and Arab land.

- Culture complexes: refers to collection of cultural traits that make up cultural requirements for a giving situation. For example extended family system in Africa, requires the recognition of relatives, close and distant. Other example may include respect for age and system of salutation.

- Culture patterns: this is a collection of certain cultural traits and complexes. For example an African cultural pattern of community emerges when traits and complexes such as presenting of kolanuts, the extended family system, and salutation practices, are brought together. Other examples include African Traditional religious Pattern, Christian Religious pattern, and Islamic Religious pattern.

\section{Transmission Of Culture}

At birth the human being is a mass of muscles, bones, blood, skin, and reflexes. The kind of persons becomes dependent on the content of a particular culture to which he/she is exposed during the process of learning ie socialisation / enculturation.

Culture is dynamic process that changes over time. This could be as a result of internal or external influence. The modification of an earlier state of culture as a result of contact with an advanced culture is called 'acculturation'. 
It has been suggested by Antonio Gramsci, Franz Fanon and Amilcar Cabral as indicated by (Barney 2006), from the perspective of revolutionary cultural theory as they assert the transformative character of culture rather than the conservative impulses of some culture practitioners. Fanon sees the role of culture as the "awakener of the people ... to speak to the nation, to compose the sentence which expresses the heart of the people and to become the mouthpiece of a new reality in action." Antonio Gramsci states that "every revolution has been preceded by an intense labour of social criticism, of cultural penetration and diffusion..." Finally for Amilcar Cabral cultural theory as in (Barney 2006)enables us to know what dynamic syntheses have been formed and set by social awareness in order to resolve these conflicts at each stage of evolution of that society in search of survival and progress..." just as in the case of African countries. The essence of these reflections is to note that culture is a necessary tool for discovery, advancement and change. ${ }^{i}$ It best expresses itself and has lasting value when it transcends the past and the present while building on them in order to better understand the present and shape (or take responsibility for) the future. Societies had to "continue to produce and make history, since just like human being, it can never free itself from the burden of itsneeds, both socially and economically, which are the basis of the development of the forces of production." Essentiallythis opens up the possibility of societies creating their own culture with each generation and new prospects for the cultural development of the society in question, by returning to that society all responsibilities for its capacity to create progress.

Surely such a cognitive openness to new styles of living, new and different understandings of one's world, and new instruments of aesthetic and intellectual engagement opens up the possibility of culture being a helpmate of education than merely a hindrance.

\section{Concept Of Education}

It is obvious there can be no universally accepted definition of Education. Different people have different ways of explaining or describing it.

- Cambridge Conference on African Education (1952) defined it as "the united concern of a people for the right upbringing of its children and improvement of national life"

- Milton (1995) "Education is that which leads a man to perform justify, skilfully and magnanimously all the offices both public and private, of peace and of wars"

- Cermin (1978) "Education is the deliberate, systematic and sustained effort to transmit, evoke or acquire knowledge, attitudes and values, skills and sensibilities and learning that results from the effort, direct or indirect, intended or unintended."

From the three definitions above, education can be seen as a process which intentionally transmit what is considered to be valuable in an intelligent and voluntary manner. Taking university education on this concept, one can identify three major characteristics:

- There is a transmission process; in University this involves teaching, research, publications, and community services.

- What is transmitted is valuable to the general population.

- The manner of transmission is acceptable by the laws of culture and the laws of the land.

At the same time university education has three dimensions:

- The academic dimension

- The psycho-motor development dimension

- The affective dimension

Higher Education in particular should foster the development of the intellectual capabilities of people and improve their reasoning powers, through imparting knowledge of principles which aid the development of intellect. On the psycho-motor dimension, university education should promote desirable physical development; it should make its clients to appreciate those practices and habits which lead to enviable status of physical health and development. The affective dimension of education should be directed toward building of right attitudes, values and norms.

The content of what is to be transmitted must have intrinsic values. This should be dictated by the values and culture of the society hosting the educational institution. Societal values should be defined by a group having the political authority iewhich is the government in power. Transmission method must also be legitimate, which is always rooted in the constitution based institution as well as in variety of informal settings (interacting with parent, peer groups religion and mass media programmes). However in all cases, the mode of transmission should be in conformity with the culture of the last society.

\section{Relationship between Culture and Higher Education}

To be useful and acceptable member of a society we need to learn and share the customs, beliefs and values of the society, which are the core content of culture. The learning process is regarded as 'Socialization processes. Higher Education on the other hand, is the process of learning to live as a useful and acceptable 
member of a society. This learning process takes place in structured as well as unstructured settings ie formal and informal settings. In a nutshell, education is synonymous with socialization or enculturation. A well cultured person is a well educated person. Thus Higher education should be directly linked with people's culture both in content and process.

In a simpler analogy, education is a process of exposing an individual to selected knowledge, skills and attitudes. In this manner education is concerned with transmission of selected contents of culture in a structured situation. While the informal situations too, also transmits the unselected contents of culture. Therefore Higher education should be learning to conform to a given cultural pattern, and this makes education and culture inseparable.

For contemporary higher education to be effective, it should integrate the values and strengths of traditional culture with the knowledge and skills required by new conditions of modern life.

Victor (1979:3), for example, concludes that the purpose of all colonialeducation was "subordination of Africans."Kofi (1964:7) recalled how schools in Ghana separated students from the life and needs of their community. For Apollo (1998:19) as cited by Barney (2006), the role of colonial education in the service of imperial domination and economic exploitation caused a number of undesirable effects, such as economic inequality, social stratification, cultural and intellectual servitude, devaluation of traditional culture, and curricula that were irrelevant to the real needs of society. Muzrui(1978:16) sheds more light on this cultural discontinuity in terms that explain the linkage of education with the rural-urban divide:

Higher education as inherited from colonial masters in African conditions was a process of psychological deruralisation. Theeducated African became ... a misfit in his own village ... when he graduated ... his parents didnot expect him to continue living with them, tending the cattle or cultivating the land.After independence African governments invested heavily in educational expansion anddiversification; the gains in enrolment, literacy, skilled human resources and educationalfacilities have been impressive given the constraints of limited resources. Many critics,however, think the system has failed to improve life for most Africans and continues todestabilise society.

One social observer, B.S. Kwakwa (cited byNwomonoh, 1998:265) reported on the social divisiveness of schooling in Ghana:The effect of the Western type of education has been to produce ... three nations in one country,each unable to communicate effectively with the others ... the 'educated,' ... many who do notunderstand the ways of the 'un-educated,' ... then ... a third group, the 'half educated' whounderstand neither the ways of their own indigenous society nor those of the 'highly educated.'Some problems identified by Uchendu (1979:1-2) include the rural-urban disparities, ethnicand geographic inequality of access to education,He also blamed schools for inculcating a culture of egocentric materialism, causing the decline of collective responsibility and contributing directly to unemployment.

A critique of the ideological foundations of African education as advanced by Mazrui(1978:13); he regards neo-colonial cultural dependency as a threat to African psychologicalautonomy and sovereignty when testifying "Very few educated Africans are even aware thatthey are also in cultural bondage. All educated Africans ... are still cultural captives of theWest." This critique of colonial and post-colonial education together with a quest foridentity has led some African intellectuals to re-examine the objectives, methods andoutcomes of traditional, pre-colonial forms of education. These studies provide perspectivesthat may become a guide for reform of education. They also offer valuable insights for postcolonial social reconstruction. Moreover, it is important to understand that traditionaleducation still exists in Africa and provides socialisation for many youth who never attendformal schools. Busia (1964:17) further clarifies the African ideal of socially centred human development: "Traditional education sought to produce men and women who were not self-centred, who put the interest of the group above personal interest."

BabsFafunwa(1982:9-10) reported that the focus of education in old Africa was social, responsibility,political participation, work orientation, morality and spiritual values. Learning was bydoing, which involved observation, imitation and participation. Kenyatta further noted that "knowledge thus acquired is related to a practical need, and is merged into activity and can be recalled when that activity is again required. Behaviour also is learned from doing things together, and is therefore directed to social activities from the outset. Education was thus closely integrated with cultural reproduction; given this experience it is no surprise that profound alienation arose later in response to the isolation of formal schools from the social realities of African communities. Traditional education integrated character-building, intellectual training, manual activities and physical education. Fafunwa (1982:9-10) again recalled: "In old Africa ... the man who combined good character with a specific skill was adjudged to be a well-educated and well-integrated citizen of his community."A major incompatibility involves the conflict between Western competitive individualism and African traditions of cooperative communalism. Mungazi (1996:50) concluded that Africans who accept Western culture must, of necessity, reject the viability of their own culture.

In the area of learning methods, indigenous reliance on field experience, active discovery and close observation reflects a progressive pedagogy and seems more likely to promote retention of learning than 
classroom-based book and test methods that dominate Western schooling. While the value of Western scientific thought in replacing superstition with tested knowledge should be encouraged sinceculture is the means which open the sources of knowledge; and education will lead to a deeper appreciation and value of culture.

Ajayi, et al (1996:192-194) who considered the reasons why Higher Education havefailed to stimulate development that improves the life of the masses in so many Africancountries, identified Nine areas needing attention in school programs. Theseincludes: elimination of disease, hunger, ignorance, and poverty; moral guidance; promotion of values; building respect for indigenous African culture; reduction of crime and violence; achievement of national integration with preservation of cultural diversity; protection of the environment; and strengthening of democracy.

In Kenya, Mali, Mozambique and Nigeria, development and education policy reflectedacceptance of economic Westernisation in the form of either capitalism or socialism, withexpansion of educational opportunity for Africans.Liberation from capitalist mentality, elimination of the negativeaspects of African traditional culture, empowerment of the masses through education, andrestructuring of schools as learning communities based on trust between teachers and pupils.Higher Education should embody goals of building social solidarity by removal of racial andtribal discrimination, emancipation of women, and cultivation of respect for science, service, and work.

\section{Ambivalence in the Role of Higher Education}

As a major custodian of values, the Higher Education system is expected to protect and pass on the accumulated cultural heritage of the society to succeeding generations, at the same time it is also looked upon as a major instrument of socio-economic transformation. For a nation to develop with an accelerated pace economically, socially and politically - that nation must have rapid changes in artefacts as well as in attitudes. A well managed Higher education system must effectuate those changeswhich result in de-emphasis of native culture in favour of foreign one. This is ambivalence in the role of Higher Education by the mangers of education.

If Higher education sector emphasised the preservation of a nation's culture, it will be taken as reactionist, material advancement will stagnate and the nation will be un-progressive. On the other hand, if it encourages rapid changes, then it will be regarded as revolutionary, destroying cultural values and upsetting cultural stability. Life becomes meaningless when people's values are abruptly destroyed. This is the role in congruency that places higher education in the cultural gap. To reduce this problem Higher Education has three options:-

$>$ Higher Education may discourage the rapid development of material culture while retaining the nonmaterial culture, which is propagating traditional values and beliefs. This may lead to retrogression in traditional values. It may lead to stagnation of material progress and minimization of material comforts. This option may not always go down well with most contemporary societies, including African Countries.

$>$ The second option is to encourage rapid changes in the non-material culture so as to accelerate the rate of cultural evolution. This calls for rapid social changes which require revolutionary political leadership. This lead to rapid demolition of the existing cultural pattern. It is only easy where an old society is subjugated by a new one which has to evolve a new culture, just as it happened in USA and Africa during colonial era, where the native values were paled into insignificance through military conquest.

$>$ Finally, Higher Education may preserve and transmit what it consider desirable of the non-material culture. That is stimulating changes in those aspects of non-material culture which tend to retard progress, and at the same time, discourage excessive and uncontrolled importation and adoption of material culture. This approached is popular in countries that are anxious of having technological progress but do not want to loose the enviable aspects of their cultural heritageeg China and Korea among others.

Whatever option a country adopts depends on the National Educational Philosophy of the Nation in question. African Countries Constitutions have provision for each countries philosophy of education. For example the Nigerian 1999 Constitution, section 18 (2) have emphasised provision of Scientific and Technological development. However careful study Nigerian Higher education has revealed lack of innovativeness in the system. Higher education has remain conservative in practice, and very slow to adopt or retained the old (African) or the new technology. Ithas remained less responsive to the needs of their communities.

Higher education in Africa is largely textbook driven, David et al (2006) said absorption of textbooks contents tend to be the measure of educational success. Teachers and students have remained bucket recipients of instructions rather than active participants in learning. Actually this may not have any beneficial effect in actual life situation. Learning is still perceived in many African countries as a discrete activity that one engages in only during the early years of life. There exist very little link between the education provided and real life situation, and little provision for lifelong education, (David et al (2006). 
Higher education is limited by time and space, age, socio-cultural environment, work-schedule and physical or mental handicaps, (UNCSTD 1996) contrary to African tradition. Information and communication technology opportunities for students to broaden the learning skills and for teachers to develop better multimedia and interactive courseware are steal weak. Studies have indicated according to David et al (2006), that learning takes place better through proper communication which is generally poor in classroom model which has just one way teaching model in which a teacher plays the active part while the students merely react. The much neglected Computer assisted Instructions can greatly complement traditional teaching to help students learn much more and much faster.

African leaders and educational managers in Africa have forgotten that nobody has yet made a successful revolution without arevolutionary theory (Barney 2006). In fact in the general evolution of humanity and of each of the peoples of which it is composed, classes appear neither as a generalised and simultaneous phenomenon throughout the totality of these groups, nor as finished, perfect, uniform, and spontaneous whole. The definition of classes within one or several human groups is a fundamental consequence of the progressive development of theproductive forces and of the characteristics of the distribution of wealth produced by the group or usurped from others..." (Tri-Continental Conference1966:3) And so it concluded: "... the level of productive forces, the essential determining element in the content and form of class struggle, is the true and permanent motive force of history".

\section{Conclusion and Recommendation}

Higher Education is supposed to be about learning the superior contents of culture. The cultural values which Higher education seeks to transmit are aggregated in the political process. Higher Education and culture are closely related. The problem of Higher Education arises from its cultural context. Higher Education is expected to protect and propagate culture and at the same time is expected to promote changes that would lead to development. This is the controversial role of higher education.

The socio-political and religious climate of Africa today call for an urgent and deliberate integration of the Philosophy of African Education with the overall philosophy and objective of Africa as a Union practically not just on paper. The governments through administrators and educational planners should ensure that African Higher Educational system is practically geared toward provision of ideals for better human relation, national and international unity, effective citizenship, economic prosperity, national consciousness and leadership training for growth. This will reduced or even eliminate the negative influence of foreign critics who indoctrinate African youth with dangerous dogmas which are inimical to cooperative existence of African Countries and their survival as members of the world community. A well plannedand managed Higher Education system can stimulate economic development, harmonised social pluralism and promote national unity most especially if the cultural and political context of such Higher Education is suitable and supportive.Higher Education should seek to “develop people's self- consciousness and an awareness of their power to make their own history..."Kenyatta (1965:118)

Kenyatta (1965:118) thought that education must maintain the traditional structures of family, kinship, sex and age grouping if African societies were to remain stable; otherwise, he foresaw the onset of social disintegration. "education should be rooted in Africa's own cultural heritage and values and have relevance to African societies."A more radical plan is favoured by Unwuachi (1972:10), who thinks that "black culturalobjectives can never be obtained by using ... white European standardized educationalprocesses." In his view, Western culture as motivated by individualism, economicexpediency, self-interest and 'superego' principles is incompatible with the Africanemphasis on collective life, economic communalism, resourcesharing, and groupobligation. He calls for a new departure in African education to build community values,strengthen the family, teach ethical standards, promote health, and develop capacity toachieve the basic needs of security and human welfare

African educational policies should focus on the priority of national development which encompassed the goals of Africanisation, national unity and economic growth. Education was to be employed to de-colonise the minds of people who had been alienated from their own culture by years of European domination. The policy also called for promotion ofAfrican and universal values.

\section{Reference}

[1]. Abernrthy D B and Coombs T (1960) Education and Politics in Developing Countries, Harvard Education Review, Volume 33 No. 3.

[2]. Adesina, S. (1981) Introduction to Educational planning. Ile-IfeUniversity of Ife Press, Nigeria

[3]. Ajayi, J.F.A., Goma, L.K.H. \& Johnson, G.A. (1996) The African Experience With Higher Education. London:James Currey.

[4]. Ceriman (1978) A Change in Education, A paper presented atsymposium, The Future of Formal education, University of Stockholm.

[5]. Barney P N (2006) Keynote Address: $6^{\text {th }}$ Ordinary Session, Assembly of Heads of State and Government of the African Union, Khartoum, Sudan23 January 2006.

[6]. Busia, K.A. (1964) Purposeful Education for Africa. London: Mouton. 
[7]. Communique of First Tri-Continental Conference of the Peoples of Asia, Africa and Latin America held in Havana, Cuba, January 1966, titled The Weapon of Theory.

[8]. David A. O. \&Olabanji E. O. (2006) Globalization and NigerianEducation System: Opportunities and Challenges, International Journal of African American Studies, Vol 5.No. 2, July Edition.

[9]. Easton D (1959) An Approach to the Analysis of Political System,World Politics, April Publication, USA.

[10]. Fafunwa, A.B. \&Aisiku, J.U. (Eds.) (1982) Education in Africa: A Comparative Survey.

[11]. London: GeorgeAllen \&Unwin.

[12]. Federal Republic of Nigeria (1999) Constitution of the Federal Republic of Nigeria, Printed by Federal Republic of igeria Press, Mobil Road Apapa Lagos.

[13]. Freire R (1968) Pedagogy of the Oppressed, New York, The SeaburyPress.Hartley H J (1968)

[14]. Educational Planning, Programme - Budgetting. Aystem approach, Englewood Cliffs, prince hall Inc. England.

[15]. Kenyatta, J. (1965) Facing Mount Kenya: The Tribal Life of the Gikuyu. NY: Vintage Books.

[16]. Mazrui, A.A. (1978) Political Values and the Educated Class in Africa. Berkeley, CA: University of CaliforniaPress

[17]. Mendoza, M G (1973) System of Society, Toronto, lexinton,Massachusetts, Healtan Co, Canada.

[18]. Micheal Armstrong (2006) Human Resource Management Practice,Tenth Edition, International Student Edition, London, Kogan Page.

[19]. Milton John (1995) Politics of Education, edited by Morris E E, Macmillan, London Mungazi, D.A. (1982) The Underdevelopment of African Education. Washington, D.C.: University Press of America.

[20]. National Policy on Education,(2004) Federal republic of Nigeria.NERDC Press, Yaba Lagos, Nigeria.

[21]. Nwankwo, J I (1982) Social and Political Context of EducationalPlanning, (Mimeograph) Ibadan, department of Educational Management, University of Ibadan.

[22]. RaoN P (2008) Education and Human Resource Management, New Delhi, APH Publishing Corporation, Darya Ganj.

[23]. Uchendu, V.C. (1979) Education and Politics in Tropical Africa.. NY: Conch Magazine.

[24]. UNCSTD, (1996) Information and Communication Technology in Development, UNESCO perspective. Available at http//www.itu.int.acc/rtc/unesco.htm.

[25]. Nwomonoh, J. (Ed.) (1998) Education and Development in Africa: A Contemporary Survey. San Francisco:International Scholars Publications.

[26]. Wirst EM and Krist M W (1972) Political Social Foundations of Education, Berkley, McCutchan Publication Co. 